\title{
The Trade Regime Complex and Megaregionals - An Exploration from the Perspective of International Domination
}

\begin{abstract}
Megaregional trade negotiations have become the subject of heated debate, above all in the context of the Transatlantic Trade and Investment Partnership (TTIP) and the Trans-Pacific Partnership (TPP). In this article, I argue that the justice of the global order suffers from its institutional fragmentation into regime complexes. From a republican perspective, which aspires to non-domination as a guiding principles and idea of global justice, regime complexes raise specific and important challenges in that they open the door to specific forms of domination. I thereby challenge a more optimistic outlook in regime complexes, which paints a positive normative picture of regime complexes, arguing that they enable the enhancement of democracy beyond the state and, consequently, have the potential to reduce the democratic deficit in global governance. By drawing attention to how regime complexes reinforce domination-related injustice, this article contributes an original perspective on megaregionals and to exploring the implications of global justice as non-domination.
\end{abstract}

Keywords: International domination; megaregional trade agreements; regime complexes; Transatlantic Trade and Investment Partnership (TTIP); Trans-Pacific Partnership (TPP), global justice

\section{Introduction}

In the recent past, megaregional trade negotiations have become hotly debated and increasingly relevant, i.e. deep integration partnerships between countries or regions with a major share of world trade. One prominent example is the Transatlantic Trade and Investment Partnership (TTIP), which started being negotiated by the European Union (EU) and the United States (US) in 2013 in an environment of already dense, complicated and overlapping existing multilateral, bilateral, plurilateral and regional agreements. TTIP as well as the megaregional Trans-Pacific Partnership (TPP), which has been recently concluded by the US and eleven other countries along the Pacific Rim, and the China-lead Regional Comprehensive Economic Partnership (RCEP) in Asia, represent a trend towards an increasingly strong regionalisation of trade governance via comprehensive free trade agreements and a progressive market opening outside the confines of the multilateral World Trade Organisation (WTO).

While the future of TTIP and TPP are not certain today, having been put on hold by the new US administration under President Trump, still the critique of 
the practices associated with megaregionals are relevant beyond these treaties themselves. The normative critique of TTIP and TPP is thus valuable even if these particular agreements were never implemented. At the same time, it is likely that the negotiations will be picked up again in one way or another in the near future, with European leaders and some high-level members of the USadministration speaking out in favour of a TTIP-restart and the so-called 'TPP 11' grouping, all TPP-members but the US, being determined to forward the agreement. Moreover, many of the arguments made in this article are relevant beyond the case of trade, for example in the context of other club governance arrangements like the $\mathrm{G} 7$ and the G20.

In which ways do the TTIP negotiations differ from the negotiations for other free trade agreements? TTIP aims to be deeper and larger than any other bilateral or regional trade agreement. Its depth, going far beyond many multilateral trade rules, the TTIP negotiations raise both trade and non-trade policy concerns, such as health and environmental protection. Moreover, due to its sheer size, representing around 30\% of global trade and $60 \%$ of global GDP, TTIP has substantial effects on third countries and systemic effects for the system at large. In light of this, I submit that, while TTIP has become the subject of heated debate, this debate often proceeds with an excessively narrow focus: The debate is primarily concerned with the impact of TTIP on Europe and the US and too little attention is being paid to the implications of this megaregional for the rest of the world and for the (in)justice of the global order. This article seeks to address the later question - in the context of viewing TTIP as part of a so-called regime complex.

TTIP, if successful, would add another component to the existing sets of bilateral and regional as well as plurilateral and multilateral agreements with partly overlapping mandate and membership, otherwise known as the 'trade and investment regime complex.' ${ }^{1}$ While regime complexes have been studied empirically and this body of research continues to grow, ${ }^{2}$ so far, there have been only few detailed assessments of such complexes from a normative

1 Christina L. Davis, 'Overlapping institutions in trade policy', Perspectives on Politics 7/1 (2009), 25-31; Amandine Orsini, Jean-Frédéric Morin and Oran Young, 'Regime complexes: A buzz, a boom, or a boost for global governance?', Global Governance: A Review of Multilateralism and International Organization 19/1 (2013), 27-39; Sophie Meunier and Jean-Frederic Morin, 'No agreement is an island: Negotiating TTIP in a dense regime complex', in Jean-Frederic Morin, Tereza Novotná, Frederik Ponjaert and Mario Telò (ed.), The politics of Transatlantic trade negotiations (Abingdon: Routledge, 2015), 173-186.

2 For instance, see Laurence R. Helfer, 'Regime Shifting in the International Intellectual Property System', Perspectives on Politics 7/1 (2009), 39-44; Drezner, Daniel, 'The Power and Peril of International Regime Complexity', Perspectives on Politics 7/1 (2009), 65-70; Joseph Jupille, Walter and Duncan Snidal, Institutional Choice and Global Commerce (Cambridge: Cambridge University Press, 2013); Thomas Hale, David Held and Kevin Young, 'Gridlock: From Selfreinforcing Interdependence to Second-order Cooperation Problems', Global Policy 4/4 (2013), 223-235; Julia C. Morse and Robert O. Keohane, 'Contested Multilateralism', The Review of International Organizations 9/4 (2014), 385-412. 


\section{THE TRADE REGIME COMPLEX AND MEGAREGIONALS - AN EXPLORATION FROM THE PERSPECTIVE OF INTERNATIONAL DOMINATION}

perspective. The question of how increasing institutional density and overlaps of international institutions should be assessed from a normative perspective has been significantly less in the scholarly limelight to date. ${ }^{3}$ More generally, research in international political theory has displayed a tendency to refrain from accounting for the fact that international institutions frequently display functional overlaps and that they often do not operate independently from each other. ${ }^{4}$

Against this background, this article focuses on TTIP and other megaregionals and how they affect the trade regime complex and its normative assessment. By putting the spotlight on regime complexes from a normative perspective, the aim is to broaden research on the proliferation and growth of regime complexes. I shall make use of a theoretical lens that focuses on (non-)domination from a republican perspective. I seek to argue that the justice of the global order suffers from its institutional fragmentation into regime complexes.

I thereby challenge a more optimistic outlook on regime complexes. In several recent contributions, Jonathan Kuyper painted a positive normative picture of regime complexes, arguing that they foster democracy beyond the nation state and that they lead to a better balancing of different policy objectives. ${ }^{5}$ In this article, I take a different position by arguing that the institutionally fragmented international system puts in place a structure that enables international domination. From a republican perspective which aspires to non-domination as a guiding principles and idea of global justice, regime complexes thus raise specific and important challenges in that they open the door to specific forms of domination. By drawing attention to how they reinforce domination-related injustice, this article contributes an original perspective on megaregionals and to exploring the implications of global justice as non-domination. ${ }^{6}$

To be more precise, I seek to argue that the focus on mega the key characteristics of regime complexes contributes to highlighting the following inter-related points: Firstly, the existence of regime complexes can generate fragmentation that is sub-optimal from a republican perspective due to institutional opacities

3 For exceptions, see Eyal Benvenisti and George W. Downs, 'The Empire's New Clothes: Political Economy and the Fragmentation of International Law', Stanford Law Review 60/2 (2007), 595-631; Sylvia I. Karlsson-Vinkhuyzen and Jeffrey McGee, 'Legitimacy in an era of fragmentation: The case of global climate governance', Global Environmental Politics 13/3 (2013), 56-78; Jonathan W. Kuyper, 'Global Democratization and Regime Complexity', European Journal of International Relations 20/3 (2014a), 620-646; Jonathan W. Kuyper, 'The democratic potential of systemic pluralism', Global Constitutionalism 3/2 (2014b), 170-199, p. 170; Jonathan W. Kuyper, 'Deliberate Capacity in the intellectual property rights regime complex', Critical Policy Studies 9/3 (2015), 317-338; Benjamin Faude and Felix Große-Kreul, 'Normative Legitimacy in Regime Complexes: Contested Multilateralism as Progress' (2016), mimeo.

4 Thomas Gehring and Sebastian Oberthür, 'The Causal Mechanisms of Interaction between International Institutions', European Journal of International Relations 15/1 (2009), 125-156; Kal Raustiala and David G. Victor, 'The Regime Complex for Plant Genetic Resources', International Organization 58/2 (2008), 277-309.

5 Kuyper (2014a, 2014b, 2015).

6 I am grateful for one of the reviewer's comments to help me formulate the contribution of this article in this way. 
and challenges for power checks this gives rise to. Secondly, while there might be cases in which overlapping institutions lead to a better balancing of policy objectives in regime complexes, regime complexes also enable problematic cross-institutional strategies that undermine any kind of balancing processes from the start, above all 'forum shopping,'7 i.e. the strategic selection of an international decision-making venue, or 'regime shifting, ${ }^{8}$ i.e. redefining the larger political context so as to ultimately reshape the system of rules itself in favour of those with power. Thirdly, the notion of regime complexes illustrates that the (in)justice of the global order depends also on the extent to which so-called 'institutional externalities', i.e. the effects overlapping international institutions create beyond their own institutional confines, amount to international domination.

The remainder of the article is structured as follows: I begin by mapping the regime complex of international trade and outline existing normative views on regime complexes before I introduce the concept of international domination. In the main body of the article, I discuss the trade regime complex, with a specific focus on megaregionals, from the perspective of international domination before the last section offers concluding comments.

\section{Mapping the Trade Regime Complex}

The 'trade and investment regime complex' (or, short, trade regime complex) is one among many other regime complexes, including the climate regime complex or the biodiversity or health regime complex. 'Regime complexes' are governance arrangements that do not consist of one single institution but of a set of inter- and transnational institutions that display overlaps in their members and / or functions but are not coordinated by an overarching institution. ${ }^{910}$

Existing scholarship indicates that regime complexes have advantages and drawbacks. On the one hand, a complex comprising a plurality of institutions is often said to provide significant opportunities. ${ }^{11}$ It enables trial and error

7 Marc L. Busch, 'Overlapping Institutions, Forum Shopping, and Dispute Settlement in International Trade', International Organization 61/4 (2007), 735-761; Jupille et al. (2013).

8 Helfer (2009); Karen J. Alter and Sophie Meunier, 'The politics of international regime complexity', Perspectives on Politics 7/1 (2009), 13-24.

9 Raustiala and Victor (2008); Alter and Meunier (2009); Robert O. Keohane and David G. Victor, 'The Regime Complex for Climate Change', Perspectives on Politics 9/1 (2009), 7-23; Kenneth W. Abbott, 'The transnational regime complex for climate change', Environment and Planning Government and Policy 30/4 (2012), 571-590.

10 A more recent definition that is more detailed refers to a regime complex as a "network of three or more international regimes that relate to a common subject matter; exhibit overlapping membership; and generate substantive, normative, or operative interactions recognized as potentially problematic whether or not they are managed effectively' (Orsini, Morin and Young (2009), p. 29).

11 Kenneth W. Abbott, Jessica F. Green and Robert O. Keohane, 'Organizational ecology and organizational strategies in world politics', Discussion paper 2013/57 (Harvard: Harvard Project on Climate Agreements, 2013). 


\section{THE TRADE REGIME COMPLEX AND MEGAREGIONALS - AN EXPLORATION FROM THE PERSPECTIVE OF INTERNATIONAL DOMINATION}

and could favour incremental adaptation to a changing environment. ${ }^{12}$ On the other hand, regime complexes are said to also come with drawbacks, such as redundancies and duplication, some confusion and the need for constant management of institutional interactions. ${ }^{13}$ Moreover, the institutional fragmentation of the international system may reduce international institutions' ability to create global public goods. ${ }^{14}$ As has been recently put forward in an edited volume on TTIP, these weaknesses could be considered as 'a fair price to pay to have a governance structure that is flexible, adaptive, creative and less vulnerable to crisis'. ${ }^{15}$ Yet, so far, it remains an open question whether this is a convincing perspective in the context of the trade regime complex.

The trade regime complex has rapidly changed over the past years. An enormous increase of actors interested in and of institutions governing trade-related issues inter- and transnationally has resulted in a complex governance architecture. What has emerged is a densely populated regime complex for international trade that features pronounced overlaps among inter- and transnational institutions and which is currently expanding in three dimensions: ${ }^{16}$

Firstly, the trade regime complex is expanding in terms of institutions. Until the 200os, the basic components of the complex were primarily intergovernmental organizations, regional customs unions and bilateral agreements. Recently, other institutional forms have mushroomed, including plurilateral sectoral agreements(e.g.theAnti-Counterfeiting TradeAgreement), venues for regulatory agencies (e.g. the International Competition Network), collaborations among intergovernmental organizations (e.g. the Standards and Trade Development Facility), private organizations (e.g. the International Accounting Standards Board) and, at the center of this article, megaregionals (e.g. TTIP and TPP). Secondly, the trade and investment complex is expanding in terms of issue areas. As hinted at in the introduction, rather than simply building on the WTO legacy with 'WTO-plus' commitments, it covers an increasing number of 'WTOextra' issues such as anti-corruption, and tax evasion. ${ }^{17}$ These issues were not initially on the WTO agenda, but are now addressed by various trade initiatives and broadening the thematic frontiers of the trade and investment complex. Thirdly, the regime complex is expanding geographically. While, until recently,

12 Joost Pauwelyn, 'At the edge of chaos: Foreign investment law as a complex adaptive system, how it emerged and how it can be reformed', ICSID Review 29/2 (2014), 372-418.

13 Frank Biermann, Philipp Pattberg, Harro van Asselt and Fariborz Zelli, 'The Fragmentation of Global Governance Architectures: A Framework for Analysis', Global Environmental Politics 9/4 (2009), 14-40.

14 Hale et al. (2013).

15 Meunier and Morin (2015).

16 These three dimensions have recently been spelled out by Meunier and Morin (2015).

17 Henrik Horn, Petros C. Mavroidis and André Sapir, 'Beyond the WTO? An anatomy of EU and US preferential trade agreements', The World Economy 33/11 (2010), 1565-1588; Richard Baldwin, 'WTO 2.0: Governance of the 21st century trade', Review of International Organization 9/2 (2014), 261-283. 
only a handful of countries were promoting trade and investment agreements, today, many countries are negotiating simultaneously on several in parallel, which underlines the high density and intricacy of the trade and investment regime complex. The trade complex is thus a system that can be analyzed as a whole. $^{18}$

\section{Positive Normative Perspectives on Regime Complexes}

To date, the existing body of normative assessments of regime complexes and institutional fragmentation is limited. As mentioned above, there are some scholars who take a positive normative perspective on regime complexes. For example, Kuyper submits that regime complexes facilitate the improvement of democracy beyond the nation state. ${ }^{19}$ According to Kuyper ${ }^{20}$, regime complexes can stimulate inclusive and consequential political discussion at the international level. Kuyper seeks to make the case that arguments put forward within one international institution may influence the discursive processes within overlapping international institutions in the regime complex and that regime complexity thus leads to the discursive inclusion of a broader range of actors and therefore to a more 'equal inclusion of interests' ${ }^{21}$ and to a better balancing of different policy objectives.

Kuyper $^{22}$ argues that key mechanisms through which these effects are brought about are 'forum-shopping'23 and 'regime-shifting'. ${ }^{24}$ In 'forum-shopping', the shopper strategically selects the venue to gain a favorable decision for a specific problem. ${ }^{25}$ In 'regime-shifting', actors may use forum-shopping or other strategies with the ultimate goal of redefining the larger political context so as to ultimately reshape the system of rules itself. ${ }^{26}$ According to Kuyper, these modes of cross-institutional action enable weaker actors to contest institutionalized inequalities and to reduce power imbalances. He argues that pursuing 'forum-shopping' and 'regime-shifting' enhances the realization of core democratic values such as equal participation and accountability. ${ }^{27}$ In this article, I seek to challenge that position, above all by arguing that less

18 Joost Pauwelyn and Wolfgang Alschner, 'Forget about the WTO: The network of relations between Preferential Trade Agreements (PTAs) and 'Double PTAs" in Andreas Dür and Manfred Elsig (ed.), Trade Operation: The Purpose, Design and Effects of Preferential Trade Agreements (Cambridge: Cambridge University Press, 2015), 497-532; Meunier and Morin (2015).

19 Kuyper (2014a, 2014b).

20 Kuyper (2015).

21 Ibid, p. 328.

22 Kuyper (2014a).

23 Busch (2007), p. 735; Jupille et al. (2013), pp. 29, 45, 141.

24 Helfer (2009), p. 39.

25 See also the notion of 'competitive regime creation' (Johannes Urpelainen and Thijs van de Graaf, 'Your Place or Mine? Institutional Capture and the Creation of Overlapping International Institutions', British Journal of Political Science 45/4 (2013), 799-827).

26 Alter and Meunier (2009), 13-24.

27 Kuyper (2014a). 
powerful states lack the ability to resort to strategies like 'forum shopping' and 'regime shifting'.

Faude and Große-Kreul ${ }^{28}$ have also recently put forward a positive normative perspective on regime complexes. They argue that regime complexes create the opportunity structure for addressing and for mediating normative conflicts among international institutions that are based on diverging policy goals: For instance, insofar as the World Trade Organization (WTO) overlaps with multilateral environmental agreements (MEAs), the WTO's objective of trade liberalization has to be balanced against environmental policy objectives. ${ }^{29} 3^{30}$ According to Faude and Große-Kreul, regime complexes 'increase the normative demand for international institutions to justify their negative externalities' ${ }^{\prime 1}$ and introduce limits on how overlapping inter- and transnational institutions may legitimately exercise their authority, reducing the 'danger that inter- and transnational institutions abuse their issue-area specific authority in a way that impinges upon the issue-area specific authority of other inter- and transnational institutions'.$^{32}$ Faude and Große-Kreul ${ }^{33}$ argue that regime complexes put in place a system of informal checks and balances (on checks and balances in regime complexes, see also Grant and Keohane 2005) ${ }^{34}$ : Regime complexes increase the pressure for institutions to justify their decisions in 'more balanced and more encompassing' ways. According to them, regime complexes thereby make it difficult for one institution to dominate the realm of overlap one-sidedly.

While it may be the case that regime complexes do provide the opportunity structure for contesting international institutions and while they do enable reflection about what constitutes the public good in a socially and institutionally fragmented international sphere, ${ }^{35}$ I shall argue that this perspective underestimates existing power inequalities, which, in the context of regime complexes, open the door for international domination.

\section{International Domination and Global Justice}

The republican concept of freedom of non-domination can be understood as

28 Faude and Große-Kreul (2016).

29 Ibid.

30 With regard to TTIP, many critics stress that it privileges economic policy goals over those of environmental and consumer protection (see Morin et al. (2015)).

31 Faude and Große-Kreul (2016), p. 4.

32 Faude and Große-Kreul (2016), p. 17. In order to make their case, Faude and Große-Kreul make use of Forst's notion of the 'right to justification' ('Recht auf Rechfertigung'). See Rainer Forst, Das Recht auf Rechtfertigung. Elemente einer konstruktivistischen Theorie der Gerechtigkeit (Frankfurt: Suhrkamp Verlag, 2007).

33 Faude and Große-Kreul (2016), p.17.

34 Ruth Grant and Robert Keohane, 'Accountability and Abuses of Power in World Politics,' American Political Science Review, 99/1, 29-43.

35 Faude and Große-Kreul (2016). 
the absence of the power to interfere arbitrarily with agents' choices ${ }^{36}$ - be they individuals or corporate agents ${ }^{37}$. Domination is the subjection to the arbitrary power of another actor. Power, in turn, can be said to be arbitrary when it is not subjected to appropriate checks and controls.

While there is a growing literature on non-domination in the global arena, ${ }^{38}$ regime complexes have not yet been addressed from that perspective. The large majority of the literature on non-domination in the global arena does not question the individualistic perspective that characterizes the domestic (neo-) republican point of view. ${ }^{39}$ However, going beyond the focus on individuals, an emerging literature is increasingly exploring the domination of states as well. ${ }^{40}$ Building on this literature, this article puts the spotlight on international domination and the domination of states.

For instance, in his recent work, Philip Pettit ${ }^{41}$ has put forward an international ideal of non-domination, in which he moves beyond the two-dimensional picture that focuses on the realization of individual freedom as non-domination through a non-dominating state by including a third dimension that takes into account the potential of states themselves being dominated. As Pettit puts it: 'In a slogan, the state ought to be an internationally undominated, domestically undominating defender of its citizens' freedom as non-domination.' ${ }^{2}$

In a recent article, Cecile Laborde and Miriam Ronzoni ${ }^{43}$ also put the spotlight on the domination of states, arguing that globalization generates new opportunities for domination and that this domination amounts to global

36 Philip Pettit, Republicanism: A theory of freedom and government (Oxford: Oxford University Press, 1997); Philip Pettit, On the People's Terms: A Republican Theory and Model of Democracy (Cambridge: Cambridge University Press, 2012).

37 Julian Culp, Miriam Ronzoni, Tamara Jugov and Laura Valentini, 'Global Justice and Non-Domination', Global Justice: Theory Practice Rhetoric 9/1 (2016), 1-27.

38 There are several perspectives on non-domination and global governance (e.g. Samantha Besson and José Luis Martí, Legal Republicanism: National and International Perspectives (Oxford: Oxford Publications, 2009); Lena Halldenius, 'Building Blocks of a Republican Cosmopolitanism: The Modality of Being Free', European Journal of International Relations 9/1 (2010), 12-30; Cecile Laborde, 'Republicanism and Global Justice: A Sketch', European Journal of Political Theory 9/1 (2010), 48-69; Cecile Laborde and Miriam Ronzoni, 'What is a Free State? Republican Internationalism and Globalisation', Political Studies, 64/2 (2016), 279-296; Frank Lovett, 'Republican global distributive justice' Diacrítica 24/2 (2010), 13-30; José Luis Martí 'A global republic to prevent global domination', Diacritica 24/2 (2010), 31-72; Philip Pettit, 'A republican law of peoples', European Journal of Political Theory 9/1 (2010a), 70-94; Philipp Pettit, 'Legitimate international institutions: A neo-republican perspective', in Samantha Besson and John Tasioulas (ed.), The Philosophy of International Law (Oxford: Oxford University Press, 2010b), 139-161; See also the Special Issue of Global Justice: Theory Practice Rhetoric 9/1 (2016)).

39 For example, see James Bohman, 'Republican Cosmopolitanism', The Journal of Political Philosophy 12/3 (2004), 336-352; James Bohman, Democracy Across Borders. From Dêmos to Dêmoi (Cambridge: MIT Press, 2007).

40 Pettit (2010a; 2010b); Philip Pettit, Just Freedom: A Moral Compass for a Complex World (New York: Norton \& Company, 2014); Philip Pettit ‘The Globalized Republican Ideal', Global Justice: Theory Practice Rhetoric 9/1(2016), 47-68; Laborde and Ronzoni (2016); Dorothea Gädeke, 'The Domination of States: Towards an Inclusive Republican Law of Peoples', Global Justice: Theory Practice Rhetoric 9/1 (2016), 1-27.

41 For example Pettit (2010a, 2010b, 2014, 2016).

42 Pettit (2014), p. 153.

43 Laborde and Ronzoni (2016). 
injustice. For example, citizens in dominated states are themselves exposed to domination since a state that does not enjoy basic non-domination loses 'internal problem-solving capacity' with respect to political issues that directly concern it: 'This occurs when states are directly enmeshed in colonial, imperial or post-colonial relations, but also when their integration into the global order operates on terms that are ostensibly non-coercive, yet exhibit features of power imbalance, dependency and arbitrariness. ${ }^{44}$ In addition to other features of globalization and the global order, TTIP, as I seek to show in this article, raises serious worries in this respect.

Going forward, we should bear in mind the following distinction between two forms of domination: increases of domination as a result of actions by other states ('dominium') and domination as a result of the exercise of international governance institutions ('imperium'). ${ }^{45}$ In what follows, while I begin with an argument that can be relevant both in the case of 'dominium' and in the case of 'imperium', the remainder of the article, while also discussing the latter type of domination, puts the spotlight on domination in the former sense, i.e. on domination between states. ${ }^{46}$

\section{International Domination in the Trade Regime Complex}

This section discusses domination in the context of megaregionals like TTIP and TPP as well as their repercussions for the multilateral system. First of all, it is crucial to clarify the normative baseline for arguing that regime complexes and institutional fragmentation contribute to international domination. ${ }^{47}$ I assume that in a world without TTIP and similar megaregional, trade issues would be regulated mainly within the multilateral WTO. Due to huge economic power imbalances between states and the informal use of arbitrary power by states in trade negotiations, even the seemingly representative WTO, can be said to be characterized by intra-institutional domination. ${ }^{48}$ Thus, I do not want to argue that there would be no international domination related to trade negotiations in the absence of megaregionals. My claim is rather that TTIP and similar agreements worsen the situation with respect to international domination in comparison to a world without TTIP and other megaregionals.

In the next three sub-sections, I shall discuss key characteristics of regime complexes that open the door to domination: firstly, their institutional opacity,

\footnotetext{
44 Ibid., p. 289.

45 I am grateful for one of the reviewers for putting the spotlight on this distinction. See also Pettit (1997).

46 Another domination-related concern, as helpfully pointed out by one reviewer, is the type of domination that might subordinate citizens of one state directly under the power of some other state, the power of some supranational governance institution, or the power of some foreign private actor e.g. corporations etc. While this is certainly a type of domination-worry that is frequently articulated by those publicly opposing TTIP and similar approaches and does deserve attention, a detailed analysis of it is beyond the scope of this article.

47 I am grateful for one of the reviewers for pressing me on this point.

48 See also Laborde and Ronzoni (2016), p. 284.
} 
secondly, opportunities for forum shopping and regime shifting and, thirdly, their repercussion on negotiations in the multilateral forum of the WTO.

\section{Regime Complexes and Institutional Opacity}

Firstly, regime complexes give rise to institutional opacities and trigger epistemic challenges. The reason is that arbitrary power is more difficult to identify and to address in regime complexes that consist of numerous overlapping institutions rather than within one single institution like the WTO. In comparison to the baseline of a world with merely one institution (or at least fewer overlapping ones), it is more difficult to pinpoint and evaluate (non)-arbitrary interference in regime complexes due to the existence of manifold crisscrossing institutions. Since domination is the subjection to power that is not appropriately checked and controlled and since institutional opacities undermine the checking and controlling of power, fragmentation inevitably leads to outcomes that are, from a republican perspective, sub-optimal. ${ }^{49}$ Domination in the context of institutional opacities can be pertinent both as a result of actions by other states ('dominium') and as a result of the exercise of international governance institutions ('imperium'), depending on who is the beneficiary of institutional opacities that prevent adequate checks and controls of the exercise of power.

\section{Megaregionals and International Domination}

Secondly, in what follows, putting the emphasis on domination between states ('dominium'), I shall begin by focusing on (1) how states are directly impacted by regime complexes that entail megaregionals before I turn to a discussion of (2) the more indirect implications they might have. In the context of assessing the more direct impact of megaregionals, I shall pay particular attention to the ability of different types of actors to make use of the changing nature of the trade regime complex and the implications of global rule-making via megaregional trade agreements.

(1) So how do megaregionals increase international domination between states? Do megaregional trade negotiations not rather provide room for more balanced justifications in the trade regime complex? According to Kuyper, as indicated above, regime complexes enable cross-institutional strategies like 'forum-shopping' and 'regime-shifting', which in turn, according to him, enable weaker actors to contest existing institutionalized inequalities and enhance the realization of core democratic values, such as equal participation..$^{0}$

49 In light of that, the relative neglect of inter-institutional effects in the international political theory literature is problematic because 'every individual is embedded in different, overlapping domination relationships, concerning different aspects of their lives' (Jens Steffek, 'The Legitimation of International Governance: A Discourse Approach', European Journal of International Relations 9/2 (2003), p. 259) and regime complexes are continuing to multiply and expand.

50 Kuyper (2014a). 
Yet, the ability to make use of such strategies strongly differs across actors. Less powerful states usually lack the ability to resort to strategies like forum shopping and regime shifting in the context of the trade regime complex while powerful states can opportunistically use these strategic approaches to create settings and / or rules in their favour. The disadvantage of poorer and weaker states in the global order is thereby reinforced because they cannot adequately take advantage of or exercise new opportunities that megaregionals offer. In comparison to states who lack power, powerful countries have much less to lose if they shift away from the WTO as a forum for multilateral negotiations and are turning towards a new type of 'megaregional forum': Because of their power, they are much less dependent on the WTO to negotiate the trade rules of the future since they can shape trade negotiations outside the WTO in their favour. In fact, the availability of cross-institutional strategies in an institutionally fragmented global order characterized by the existence of manifold regime complexes is, at least in part, 'the result of a calculated strategy by powerful states to create a legal order that both closely reflects their interests and only they have the capacity to alter' ${ }^{51}$

Less powerful countries, in contrast, depend more on the multilateral forum of the WTO than those with power. They need the multilateral forum of the WTO in order to build coalitions to be able to defend their needs and interests - and in many cases to have a voice in the first place. The WTO is the negotiation framework in which developing countries can assert their interests more effectively than during megaregional negotiations, where they often lack the upper hand - if they are involved at all and not excluded from the start like in the case of TTIP. In the WTO, especially during the more recent sets of negotiations, less powerful countries have typically joined forces and successfully built coalitions in order to oppose trade rules that were not in their interest or negotiate in favour of trade rules they preferred and that corresponded to their national development levels. ${ }^{52}$ However, negotiations in sub-groups beyond the multilateral system - e.g. in the context of megaregional negotiations limit this kind of coalition-building, which allows advanced economies to play competing trade partners off against one another.

In sum, poorer and weaker states cannot adequately take advantage or exercise new opportunities that regime complexes open, thereby worsening their relative

51 Benvenisti and Downs (2007), p. 596.

52 Kristen Hopewell, 'Multilateral trade governance as social field: Global civil society and the WTO', Review of International Political Economy 22/6 (2015), 1128-1158. 
position, which amounts to a restriction of their freedom as non-domination:53 The availability of cross-institutional strategies in an institutionally fragmented global order thus enables domination by powerful actors. Regime complexes contribute to structurally undermining the freedom of states in problematic ways and contribute to injustice by increasing the potential for, or the existence of, domination.

The above also underlines that less powerful countries are directly affected by being exposed to stronger domination in the context of megaregional negotiations rather than in multilateral negotiations in the WTO due to their more direct exposure to power inequalities in light of much fewer (e.g. in the case of TPP) or no options (e.g. in the case of TTIP) for coalition-building. To illustrate, consider the example of the case of Vietnam in the context of the TPPnegotiations. For instance, TPP offered the US 'a bargaining chip to demand compliance with labour standards,' which the US used to ask Vietnam to sign a bilaterally negotiated 'Labour Action Plan'. ${ }^{54}$ Whereas improving workers' rights is an important objective from a normative perspective, developing countries often view it as a challenge that might decrease their competitive advantage and therefore hesitate to take on binding commitments in that regard. ${ }^{55}$

More generally, TPP confronts developing countries with many issues with ambivalent development impacts that, so far, do not figure prominently at the multilateral level, including commitments on investment or stricter rules on intellectual property rights. For example, protection for investors mainly caters to the interests of industrialized countries, with $85 \%$ of all related investor-state complaints originating from there and with developing countries frequently being disadvantaged by the burdens of a strict investment protection regime. ${ }^{56}$ While developing countries and many emerging economies have successfully opposed including these issues in multilateral trade negotiations due to effective coalition-building in light of their questionable development impacts (Hopewell 2015), they are now re-entering through the back door in the context of multiregionals. For example, TPP includes rules that strengthen intellectual property rights, which could make it harder to access affordable medication. ${ }^{57}$

53 As one reviewer rightly pointed out, a restriction on freedom of states in the international context is not necessarily bad; for example, environmental protection regulations may limit the freedom of states but would not necessarily constitute an injustice. However, in the case under consideration, the restrictions at stake are indeed problematic because they amount to arbitrary interference while limiting many states' freedom to have a say in shaping the trade rules of the future.

54 Clara Weinhardt and Fabian Bohnenberger ‘Trade agreements. Risks of TTIP and TPP’, Development and Cooperation 08 (2015), p. 34.

55 Ibid.

56 Ibid., p. 34

57 Brook K. Baker, 'Trans-Pacific Partnership Provisions in Intellectual Property, Transparency, and Investment Chapters Threaten Access to Medicines in the US and Elsewhere', PLoS Medicine 13/3 (2016). 
Let us return to the question of the relevant baseline and whether there would indeed be less domination in the absence of TTIP and similar megaregional agreement. Trade-rule-making on the basis of megaregional trade agreements entails more inequality than multilateral trade-rule-making because less powerful countries have fewer - if any - opportunities to create coalitions to veto the proposals of the more powerful or shape trade-rules in line with their needs and interests. Moreover, megaregional negotiations are much less formalized than multilateral ones. Informal institutions, which are characterized by rules that are vague or non-binding, ${ }^{5}$ typically structurally favour powerful over weaker actors because they enable them to take advantage of the flexibility of informality to their own benefit. In sum, the dominating nature of the megaregional approach to rule-setting thus becomes apparent once we compare it to the situation without megaregionals when other states used to have more input into the making of global trade-rules.

In addition, megaregionals give rise to concerns because they preclude numerous countries from the negotiations that determine future global trade rules. Megaregionals are attempts by the old powers, above all the US and the EU, to set new rules of play for the world economy. ${ }^{59}$ These trade rules then become the new 'standard' trade rules and are being 'diffused' globally by the EU and the US when they use them as blueprints once they start negotiating with other countries. Third parties, i.e. all the countries excluded from megaregional negotiations, are likely to have to agree to them in future negotiations with the EU and the US; these third parties thus end up being rule-takers with regard to many of the important trade rules of the future.

The setting of global rules and standards by powerful actors constitutes a wrong insofar as the old powers shape future global trade rules in line with their interests. Many of these trade rules negotiated in the context of megaregionals, as indicated above, are in conflict with developing countries' needs and interests, with dubious effects on their economy and potentially on their internal problemsolving capacities, in turn undermining domestic justice. Megaregionals thus also raise concerns from a global justice perspective because they have important implications due to their ambition to create global rules that are likely to go

58 Kenneth W. Abott and Duncan Snidal, 'Hard and Soft Law in International Governance, International Organization 54/3 (2000), 421-456.

59 Heribert Dieter, 'The Return of Geopolitics. Trade Policy in the Era of TTIP and TPP' in Anabel González (ed.), Megaregional Trade Agreements Game-Changers or Costly Distractions for the World Trading System? (Berlin: Friedrich Ebert Stiftung, 2014). 
against the interest of less powerful developing countries. ${ }^{60}$

In the context of megaregionals, developing countries fear being left behind, especially in relation to their export competitors, and are exposed to power inequalities even if they are not involved in any negotiations with powerful countries; they are thus increasingly under pressure, due to the huge market power of megaregionals, to adopt the kind of trade rules and standards the megaregional negotiating partners have taken on - even if they are not negotiating with the major megaregional powers. The arbitrary interference megaregional negotiations give rise to, arguably amounting to a case of international domination, can thus be pertinent even if there is no direct interference. ${ }^{61}$ To illustrate: Some of the developing countries affected by Vietnam's improved market access to the US due to the Vietnamese economy being part of the TPP negotiations, e.g. Pakistan or Bangladesh, are considering to join TPP in the future to protect their export competitive industries, despite not really being ready to adopt many of the agreement's provisions on the controversial issues just mentioned and despite having had no opportunity to help shape the megaregional. ${ }^{62}$

(2) This shows that, in addition to domination by states in more or less direct ways, domination can also occur while direct interference is absent. ${ }^{63}$ Note that even if third countries that are not part of negotiations for TTIP, TPP or similar approaches, will never be directly or indirectly pressured into taking over rules and standards, megaregionals will generate negative economic consequences for them. One reason for negative effects of megaregionals on third countries is that such trade agreements - in contrast to multilateral ones - lead to trade diversion effects for excluded parties, as already argued in Jacob Viner's ${ }^{64}$ seminal work. For example, in the case of TTIP, EU goods would become relatively cheaper for US consumers and 'the US will substitute away from third countries' goods towards EU goods.' 65 Poor developing countries excluded from megaregionals are therefore likely to suffer losses in trade and competitiveness,

60 Countries that are relatively insignificant in terms of their status as economic and geopolitical partners have the most to fear from megaregionals, as they have no involvement whatsoever in drafting the rules of the future; emerging economies, on the other hand, are in a better position to enter the competition for regional trade partnerships as a result of their economic and political weight and shape their future, as demonstrated by China's involvement in the RCEP negotiations with 15 other Asian countries. In contrast to this, African countries have yet to participate in negotiations regarding a megaregional agreement and risk becoming even more marginalized in the future.

61 When 'poor countries ingratiate themselves to please the richer states they depend upon, without the stronger states making any explicit demand or threat, we have a paradigmatic case of international domination without interference' (Laborde and Ronzoni (2016), p. 289).

62 Fabian Bohnenberger, 'Megaregional Agreements and Global Trade Governance: Ensuring Openness and Inclusiveness in an Increasingly Complex System', Bridges Africa 5/4 (2016).

63 Laborde and Ronzoni (2016), pp. 289-290.

64 Jacob Viner, The Customs Union Issue (New York: Carnegie Endowment for International Peace, 1950).

65 Gabriel Felbermayr and Rahel Aichele, How to make TTIP inclusive for all? Potential impacts of the Transatlantic

Trade and Investment Partnership (TTIP) on developing countries (München: Bertelsmann Stiftung, 2015), p. 6. 
not least because of preference erosion. Since megaregionals redirect trade flows, these countries also have a harder time accessing capital and technology. Simulations of the implications of TTIP indicate that a number of developing countries should expect to suffer losses. ${ }^{66} 67$ Being subjected to this form of arbitrary interference, and hence domination, can affect the internal problemsolving capacities of these states, which in turn undermines domestic justice.

So far, I have put the spotlight on domination between states ('dominium'). The other type of domination, which occurs as a result of the exercise of international governance institutions ('imperium'), is relevant, for example, when states only face one large and powerful international governance institution, from which there is no escaping. It has been argued that this is the case, for example, in the context of the WTO. ${ }^{68}$ At first sight, one might therefore argue that, at least in this respect, the rise of megaregionals, offering alternatives to and potentially limiting domination by the WTO, and the trend towards the fragmentation of the trade regime is domination-reducing rather than the opposite. ${ }^{69}$ Yet, as argued in the next section, the creation of alternatives in the WTO is likely to even increase domination in the context of the WTO. ${ }^{70}$

\section{Megaregionals and Repercussions on the Multilateral System}

The extent to which institutions open the door for international domination can also depend on the effects these institutions create on other international institutions and their governance domains. In other words, there is a need to analyze 'institutional externalities' when we assess the justice of the global order, i.e. the effects international institutions create beyond their own institutional confines, including on other (democratic) international institutions: I submit that an assessment of international domination needs to be sensitive to the effects international institutions create in domains that lie beyond their own.

In the case of megaregionals, one pertinent question is how they affect the

66 Rahel Aichele, Gabriel J. Felbermayr and Inga Heiland, 'Going Deep: The Trade and Welfare Effects of TTIP', CESifo Working Paper No. 5150 (München: ifo Institut - Leibniz, 2014); Gabriel Felbermayr, Wilhelm Kohler, Rahel Aichele, Günther Klee and Erdal Yalcin, Potential impacts of the Transatlantic Trade and Investment Partnership (TTIP) on developing and emerging economies (München: ifo Institut - Leibniz, 2014).

67 At the same time, the overall increase in demand in the US as a result of an agreement with the EU can also benefit some third countries; the net effects thus varies across countries. In the case of standards, the ramifications of megaregionals in third countries in part depend on whether and how the major negotiating partners, say the EU and the USA, agree on the harmonization or the mutual recognition of one another's varying standards. Enlarged export markets as a result of unified standards offer opportunities to those third countries able to fulfil the aforementioned standards. However, developing countries, in particular, are frequently unable to achieve the standards demanded by the EU and the USA without additional support.

68 Joshua Cohen and Charles Sabel, 'Extra rempublicam nulla justitia?', Philosophy and Public Affairs 34/2 (2006), $147-175$.

69 I am grateful for one of the reviewers for pressing me on this point.

70 Moreover, it has to be kept in mind that the WTO is a member-driven organization and, in that sense, it can be doubted whether the conceptualization of domination as 'imperium' makes much sense at all in the WTO-context. 
multilateral trading system. ${ }^{71}$ I shall argue that megaregional negotiations have important repercussions by strongly intensifying the exposure of less powerful states to power inequalities within multilateral negotiations. The reason is that TTIP and TPP increase the pressure, especially on less powerful states, to make compromises in the WTO for fear the US and the EU will lose all interest in the multilateral forum. The US has made clear that without a new agenda in line with US interests in the WTO, this is what is likely to happen. ${ }^{72}$ Indeed, against the background of the proliferation of megaregional agreements, at the 2015 WTO Ministerial, many member states were under immense pressure to agree to the proposed Nairobi outcome because the lack of any outcome could have contributed to undermining the WTO even more. In the words of a commentator, the lack of an outcome in Nairobi would have fostered 'the end of the consensus-based organization as a meaningful negotiating forum and usher in an era dominated instead by megaregional deals like the Trans-Pacific Partnership, where the US gets to choose who's in and who's out' ${ }^{73}$ According to other observers, if developing countries are 'not going to play ball in the WTO, the US and EU will pick up the ball and go play somewhere else.' From normative perspective, as argued above, this would be highly regrettable. Especially less powerful, poorer countries need the WTO to get their voices heard. If, like in the case of the WTO, the outside options are better for the dominant member states than for the subordinate ones, deadlocks within existing institutions can lead to stronger domination within and by existing institutions and to the creation of new institutions, for example in the context of regime shifts, which do not only tend to reproduce but may even deepen inequalities compared to the status quo ante of the original institution at stake.

\section{Conclusion}

The analysis of megaregionals as part of the trade regime complex from the perspective of international (non-)domination shows that the justice of the global order suffers from its institutional fragmentation because this structural feature enables strong states to dominate weaker ones. Regime complexes open the door for international domination - and TTIP and other megaregionals offer an illustration of that process.

I have argued that regime complexes generate problematic institutional

71 On this point, see also the article by Risse in this Special Issue.

72 According to an expert from the American Enterprise Institute: 'if the US told other countries directly to "put up or shut up," or they'll focus instead on talks with the European Union and adding countries to TPP, it would get results. "People are underestimating the centrality of the U.S. to this," he said. "We can coerce everybody." See Victoria Guida, 'Nairobi is make-or-break moment for WTO' (2015), <http://www.politico.eu/article/nairobi-kenya-makeor-break-moment-for-wto-trade-agreement-global-commerce-us-eu/> (Accessed: 30 July 2017).

73 Guida (2015). 
opacities and enable cross-institutional strategies like forum shopping and regime shifting that open the door for international domination and that the (in)justice of the global order depends also on the extent to which institutional externalities and inequalities amount to arbitrary interference and hence international domination. Moreover, I have argued that the mechanisms of forum shopping or regime shifting underline the importance of situating power relations in individual organizations, e.g. the WTO, within a larger institutional context, i.e. the regime complex of trade. The shopping as well as shifting benefits some members of the pre-existing regime of the WTO, namely the dominant ones, more than others by allowing them to opt for a forum more likely to produce their preferred outcomes.

Regarding megaregionals, I have argued that TTIP shows that domination does not only occur through supra-national institutions or private actors or direct state domination but can also take place in more indirect ways: TTIP is a bilateral institution that is shaped by two powerful trade partners but that has implications for the system at large, which causes global repercussions, above all for those with less power, and raises concerns about international domination. Relatedly, TTIP illustrates that arbitrary power is not just (ab)used within existing institutions but also to set-up new ones. As indicated above, this is relevant beyond the case of trade, e.g. in the context of the G7 and the G20. TTIP is hence not only an important and interesting case in order to reflect on regime complexes from a normative perspective but also to ponder the role of club governance. Club governance can be problematic if there are strong externalities, i.e. when exclusive clubs set rules that have global implications. TTIP is an example of a club that sets the club rules for its members but, at the same time, has global effects and sets rules that are likely to be a blueprint for other institutions in the future, to which states will be subject that have not had a say in TTIP and the set of trade rules it generates.

It is often being argued that the institutions that govern the global economy and their policies have been biased against developing countries and have contributed to persisting international inequalities as, for the most part, developing countries did not belong to the group of powerful actors in global governance. But as countries such as China, India and Brazil are becoming 
more and more important ${ }^{74}$, the dominance of the old powers is said to have come increasingly under pressure. In light of these developments, it has been discussed whether the rising powers challenge the existing international economic order and whether they foster alternative and potentially more equitable approaches to governing the global economy. ${ }^{75}$ A closer look at more recent developments in the global trading system indicates that the traditional powers actually seem to retain their dominance in global trade governance with institutional inequalities being reproduced and even deepened within and beyond the WTO. ${ }^{76}$ The powerful increasingly abandon the WTO to pursue their interests outside of the multilateral system, at the cost of the weakest states in the international system. Megaregionals hence suggest that we might have to pay more attention to the dynamics between old and newly rising powers and how these dynamics affect the global order and the scope for domination.

What does this imply for fostering non-domination in the global realm? According to Laborde and Ronzoni, ${ }^{77}$ there is a need for stronger institutional regulation of global affairs to safeguard the basic non-domination of states and to achieve this objective, we need to pursue a multifaceted strategy, which includes power countering, distribution, democratization, constitutionalization and regulation. The first option, so-called 'power countering', suggests that until we realize the non-domination of states, we 'have reasons to support strategies of resistance on part of those states which are more likely to be at the worse end of international domination' ${ }^{78}$ As they mention, power countering can lead to impasse and this is what happened in the context of the WTO Doha negotiations where rising powers started to resist. Yet, as indicated above, this strategy was, at least in some ways, counter-productive: international domination was arguably not avoided but intensified, namely outside the WTO due to regime

74 Mark Beeson and Stephen Bell, 'The G-20 and international economic governance: Hegemony, collectivism, or both?', Global Governance: A Review of Multilateralism and International Organizations 15/1 (2009), 67-86; Andrew Hurrell, 'Hegemony, Liberalism and World Order: What Space for Would-be Great Powers?', International Affairs 82/1 (2016), 1-19; James H. Mittelman, 'Global Bricolage: Emerging Market Powers and Polycentric Governance', Third World Quarterly 34/1 (2013), 23-37; Matthew D. Stephen, 'Rising Regional Powers and International Institutions: The Foreign Policy Orientations of India, Brazil and South Africa' Global Society 26/3 (2012), 289309; Alasdair R. Young, 'Perspectives on the Changing Global Distribution of Power: Concepts and Context, Politics' Special Issue TOC 30/1 (2010), 2-14.

75 Antonio Negri and Michael Hardt Empire (Cambridge: Harvard University Press, 2001); Jan Nederveen Pieterse, 'After Post-Development', Third World Quarterly 21/2 (2000), 175-191; Gerard Strange, 'China's Post-Listian Rise: Beyond Radical Globalisation Theory and the Political Economy of Neoliberal Hegemony', New Political Economy 16 (2011), 539-559; Peter Evans, 'Is an Alternative Globalization Possible?' Politics \& Society 36/2 (2008), 271-305.

76 One might even have to question whether apparent power shifts in global economic governance away from the traditional powers are more symbolic or superficial than real (Beeson and Bell (2009); Sanjay Pinto, Kate Macdonald and Shelley Marshall, 'Rethinking Global Market Governance. Crisis and Reinvention?', Politics and Society 39/3 (2011); Paola Subacchi, 'New power centres and new power brokers: are they shaping a new economic order?', International Affairs 84/3 (2008), 485-498.

77 Laborde and Ronzoni (2016), pp. 291-293.

78 Ibid., p. 292. 
shifting towards megaregionals, from which many rising powers are excluded. Megaregionals hence stress the difficulties of achieving the right kind of nondomination strategy. They show, for example, that the strategy of power countering can have unintended consequences and might backfire, especially for the weakest states in the international order.

Future research should focus on discussing and investigating the right kind of strategy to avoid international domination against the background of mushrooming regime complexes. For instance, the impact of TTIP on developing countries and on the global order depends on the manner in which the agreement is drafted and what kind of trade rules they contain. ${ }^{79}$ More generally, scholars might discuss and investigate, for instance, to what extent the increasing relevance of regime complexes might call for novel strategies to safeguard basic non-domination, say on the basis of some sort of rules that regulate the creation of new institutions that have global implications or on the basis of more extensive constitutionalization.

Clara Brandi

Senior Researcher

Deutsches Institut fur Entwicklungspolitik /

German Development Institute

email:clara.brandi@die-gdi.de

\section{- the global justicenetwork}

79 Felbermayr and Aichele (2015) 